\title{
Study of Phosphorus Metabolism in Thyrotoxic Myopathy
}

\section{Hisayuki KOWA}

\author{
Second Department of Internal Medicine, Toho University School of Medicine \\ (Director : Prof. Tatsuo Abe)
}

Phosphorus metabolism and creatine phosphokinase activity in muscle of thyrotoxicosis were studied biochemically. Serum creatine phosphokinase activity and significance of these abnormalities in relation with clinical signs and symtoms in thyrotoxic myopathy were also investigated. In addition, similar investigations were done in experimentally produced tyrotoxic rats for confirmation of the results obtained from clinical materials.

Method :

Inorganic phosphorus (IP), creatine phosphate (CP), adenosine triphosphate, measured as $\Delta 10 \mathrm{P}(\mathrm{ATP})$ and creatine phosphokinase activities were measured directly in frozen muscle tissu, prepared in saturated dry-ice acetone solution.

Material were obtained from 102 patients with thyrotoxicosis, and as controls 44 patients with simple goiter and 19 normal subjects.

Diagnosis of thyrotoxicosis was established clinically, and BMR, PBI, ${ }^{131}$ uptake were carefully studied in the laboratory.

Biopsy specimens were obtained from sternocleidomastoid muscles under local anesthesia with $0.5 \%$ novocain solution. Serum was taken during fasting state in the morning and materials were measured biochemically as soon as possible.

Experimental thyrotoxic rats were produced by subcutaneous injection of thyroxine $2 \mathrm{mg} / \mathrm{kg}$ for 3 weeks and sacrified for the analysis as described previously.

Results :

(1) In muscles of the thyrotoxic patients and the controls, inorganic phosphorus levels were not different materially. Howerer, creatine phosphate and adenosine triphospate values were lower in muscles taken from patients with hyperthyroidism. The 44 per cent decrease in creatine phosphate and the 26 per cent drop in adenosine triphosphate were both highly significant statistically.

(2) Serum creatine phosphokinase were measured in 61 thyrotoxic patients, 18 none-toxic goiter and 15 normal subjects. These mean values were $5.9 \pm 4.6(\mathrm{u} / \mathrm{hr} / \mathrm{ml})$, $3.3 \pm 1.7$ and 2.4 \pm 1.7. Creatine phosphokinase activities in serum in thyrotoxicosis was elevated significicantly.

(3) Muscle creatine phosphokinase activities were measured in 27 thyrotoxic patients, 16 none-toxic goiter and 4 normal subjects. Creatine phosphokinase activities were diminished in one third of the muscles taken from thyrotoxic patients but the difference was not of statistical significance. 
(4) These was no correlation between thyroid function tests and creatine phosphate, and adenosine triphosphate contents or creatine phosphokinase activities in muscle in thyrotoxicosis. However, between grip strength and levels of adenosine triphosphate or of creatine phosphokinase activities in muscles from thyrotoxic patients, some degee of correlation was proved statistically.

(5) Similar results were obtained in experimental thyrotoxic animals.

(6) The possible role of phosphorus metabolism in pathogenesis of thyrotoxic myopathy was discussed.

(pp. $42 \sim 50)$ 


\title{
Thyrotoxic myopathy の燐酸代謝に関する研究
}

\author{
東邦大学医学部第二内科学教室 (主任: 阿部達夫導 : 教 授 \\ 古和 久 幸
}

(昭和39年10日21日受付)

\section{緒 言}

甲状腺機能充進症に筋の萎弱及び萎縮を伴うととは古くから知られている ${ }^{1)}$. 高度の筋萎弱と萎縮を主症 状としている甲状腺機能充進症は臨床的には特異なものと考えられ Chronic thyrotoxic myopathy と呼ば れて特に注意を払われている2).

著者らは ${ }^{34)}$ thyrotoxic myopathy が甲状腺機能六進症に広く存在するととを臨床的に観察し，又病理， 組織学的にも証明してきたが，てれらの myopathy 発生に関する生化学的検討は欧米においても本邦におい ても行われていない.

甲状腺ホルモンが oxidative phosphorylation の uncoupler として働らくととはHoch ら ${ }^{5)}$, Maley ら ${ }^{6)}$, Johonson ら ら〕よつて報告されており， thyrotoxic myopathy と燐酸代謝障害との間に密接な関係のある ことは容易に想像される。しかしながら，甲状腺中毒症の筋肉エネルギ一代謝の中心である Creatine 燐酸 (以下 CP), ATP 亿関する報告は全くみられず，唯 Wang ${ }^{8)}$, Bodansky ${ }^{9}$ が Thyroxine 投与家鬼の筋肉にお ける GP の減少を報告しているに過ぎない.

著者は甲状腺機能穴進における筋肉の憐酸代謝異常が電解質及び Creatine 代謝障害と共に thyrotoxic myopathy の発生機序に重要な役割を占めているものと考元，甲状腺中毒症患者の筋肉を biopsy しそのł の無機燐(以下 IP)， CP, ATP を測定し, 又 CP, ATP 代謝江関与する酸素である Creatinephosphokinase (以下 $\mathrm{CPK}$ )を筋肉内及び血清で測定し興味ある知見を得たのでててに報告する。

\section{実 験 方 法}

\section{(1) 筋肉内 IP, CP, ATP の測定}

甲状腺中毒症患者中握力の低下せるもの14例及び対照として非中毒性甲状腺腫患者11例の脑鎖 乳乫筋約 100 200mgを手術時 $2 \%$ ノボカイン局所麻酔後速やが biopsy し, 直ちに Dry-ice acetone 飽和液にて 約一 $30^{\circ} \mathrm{C}$ に東結する. 次いで Torsion-Blance にて速やかに科量後, 凍結した筋肉を滤紙にはさんで木槌に て粉砕し, 予め冷却しておいた Blender に入れ，5\%卜リクロール醋酸を総量 $10 \mathrm{ml}$ になるよう速やかれ加 え氷にて冷却しながら 20 秒間 homogenizeし，直ちに濾過する，その滤液 $1 \mathrm{ml}$ を可及的速がとり MartineDoty 氏法 ${ }^{10}$ とょり IP を測定した。次いで更に滤液をそれぞれ $1 \mathrm{ml}$ 使用して CP, ATP を Allen 氏法 ${ }^{11} に$

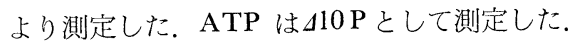

\section{(2) 筋肉内 CPK 活性の測定}

甲状腺中毒症患者 27 例，対照として非中毒性甲状腺腫患者16例の胸鎮乳突筋を同様に biopsy し（約200 $\mathrm{mg})$, dry-ice 飞て冷凍, その後 Torsion-Balance にて科量し $0.02 \mathrm{M} \mathrm{NaHCO}_{3}$ 液を組織量の49倍加え, Potter's glass Blender にて水水中にて homogenize し, 冷凍遠沈 $\left(-4^{\circ} \mathrm{C}, 6000\right.$ 回転, 10分間) 後上清を とり，更に上清を蒸溜水にて scale over にならないように稀秎して筋 CPK 活性在測定した。測定方法は Kuby·Noda·Lardy 氏変法 ${ }^{12}$ 亿従つた。

(3) 血清 CPK 活性の測定

血清 CPK 活性測定は甲状腺中毒症患者61例，非中毒性甲状腺患者18例及び健康者15例について行なつた。 
採血は早朝又は空腹時に行ない， $1 \sim 2$ 時間氷室にて静置後血清を分離し，24〜48時間以内に測定した。 血 清は採取後測定迄水室に凍結保存した。測定方法は筋肉同様 Kuby·Noda・Lardy 氏変法を用いた。

尚, 甲状腺中毒症及び非中毒性甲状腺腫の診断は臨床症状と共に BMR, PBI, I ${ }^{131}$ uptake を行つて判定 し, 又殆んど全症例切除甲状腺の組織学的検索の上判定を行つた。

\section{(4) 動物実験}

実験的 thyrotoxic myopathy を作製する目的で，体重 $100 \mathrm{~g}$ 前後の同腹の雄ラッテにサイロキシン 2.0 $\mathrm{mg} / \mathrm{kg}$ を経皮的に投与した。休重減少, 尿中クレアチン, クレアチニン排泄量を測定し thyrotoxic myopathy の指標とした。サイロキシン投与 3 週間後にエーテル林酔下に四頭股筋を切除し，飽和 dry-ice aceton で 凍結固定し，IP， CP, ATP 及び CPK 筋活性を測定した。測定方法は前述を间様である.

\section{実 験 成 績}

〔A〕燐酸代謝：筋肉内 IP, GP, ATP の成績は Table 1 及びFig. 1 の如くである.

i）無機燐 (IP.) : IP では対照群最高 $12.6 \mathrm{mg} / 100 \mathrm{~g}$ Muscle wet weight (以下 Mus. w.w と略す), 最低 $5.2 \mathrm{mg} / 100 \mathrm{~g}$ Mus. w.w. で対照群11例の平均は $8.8 \pm 2.9 \mathrm{mg} / 100 \mathrm{~g}$ Mus.w.w. であり, 甲状腺中毒症群では 最高 $10.0 \mathrm{mg} / 100 \mathrm{~g}$. Mus. w.w., 最低 $3.8 \mathrm{mg} / 100 \mathrm{~g}$. Mus. w.w で14例の平均は $7.2 \pm 2.0 \mathrm{mg} / 100 \mathrm{~g}$. Mus. w.w. である，又雨者に差異はみとめられなかつた。

Table 1. Muscle Phosphorus and Thyroid Function

\begin{tabular}{|c|c|c|c|c|c|c|c|c|c|c|}
\hline & \multirow{2}{*}{ Name } & \multirow{2}{*}{\multicolumn{2}{|c|}{ Age/Sex }} & \multicolumn{3}{|c|}{ Phosphorus } & \multicolumn{3}{|c|}{ Thyroid Function } & \multirow{2}{*}{$\begin{array}{c}\text { Grip } \\
\text { Strength } \\
(\mathrm{kg})\end{array}$} \\
\hline & & & & $\begin{array}{l}\text { IP } \\
\text { mg }\end{array}$ & $\begin{array}{c}\text { GP } \\
/ 100 \mathrm{~g}\end{array}$ & $\begin{array}{c}\text { ATP } \\
\text { Mus w.w. }\end{array}$ & $\begin{array}{c}\text { BMR } \\
(\%)\end{array}$ & $\begin{array}{l}\text { PBI } \\
(\gamma / \mathrm{dl})\end{array}$ & $\mid \begin{array}{c}\mathbf{I}^{131} \text { uptake } \\
(\%)\end{array}$ & \\
\hline \multirow{14}{*}{ 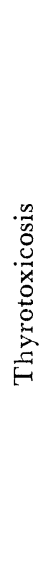 } & K.N. & 12 & $f$ & 8.0 & 28.0 & 23.4 & 55 & 11.8 & 72 & 2 \\
\hline & T.S. & 39 & $f$ & 5.6 & 19.2 & 25.8 & 33 & 8.6 & 52 & 0 \\
\hline & S.N. & 30 & $\mathrm{~m}$ & 6.0 & 20.9 & 40.6 & 81 & 16.3 & 62 & 27 \\
\hline & K.M. & 27 & $\mathrm{f}$ & 9.8 & 22.0 & 46.6 & 24 & 7.3 & 80 & 10 \\
\hline & $\mathrm{Y} \cdot \mathrm{J}$. & 40 & $\mathrm{f}$ & 3.8 & 20.4 & 27.1 & 44 & 8.3 & 69 & - \\
\hline & A.S. & 52 & $f$ & 5.0 & 18.2 & 41.1 & 54 & 13.0 & 61 & 1 \\
\hline & S.A. & 37 & $f$ & 7.5 & 24.6 & 44.0 & 54 & 9.5 & - & 2 \\
\hline & A.S. & 28 & $\mathrm{f}$ & 10.0 & 15.5 & 37.3 & 80 & 13.6 & - & 7 \\
\hline & N.G. & 42 & f & 8.2 & 23.3 & 21.5 & 33 & 7.9 & - & 1 \\
\hline & K.K. & 48 & $\mathrm{f}$ & 9.4 & 29.0 & 40.0 & 23 & 7.8 & - & 7 \\
\hline & S.S. & 26 & $f$ & 5.8 & 21.0 & 30.5 & 31 & 9.2 & - & 3 \\
\hline & K. F. & 27 & $\mathrm{~m}$ & 5.1 & 22.9 & 30.0 & 52 & 10.2 & 68 & 23 \\
\hline & K. T. & 14 & $\mathrm{f}$ & 5.4 & 14.8 & 21.0 & 42 & 7.9 & 28 & 3 \\
\hline & S.T. & 46 & $\mathrm{f}$ & 9.0 & 27.1 & 43.1 & 45 & 10.0 & 77 & 7 \\
\hline \multirow{11}{*}{ 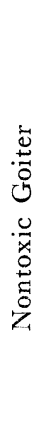 } & K.O. & 45 & $\mathrm{f}$ & 5.2 & 44.2 & 60.6 & 11 & - & 5 & \\
\hline & F.N. & 42 & f & 11.2 & 40.4 & 55.5 & 7 & - & 15 & \\
\hline & M.K. & 28 & $\mathrm{f}$ & 10.0 & 34.2 & 38.9 & 9 & - & 25 & \\
\hline & K. I . & 23 & $\mathrm{f}$ & 12.3 & 37.0 & 30.2 & 19 & - & 16 & \\
\hline & M. S. & 45 & $\mathrm{f}$ & 11.5 & 34.2 & 40.8 & 20 & - & 9 & \\
\hline & Y.Z. & 11 & $\mathrm{f}$ & 7.5 & 40.1 & 32.6 & 15 & - & 5 & \\
\hline & T.Y. & 42 & $\mathrm{f}$ & 4.8 & 49.6 & 67.6 & 20 & - & 8 & \\
\hline & K. S. & 33 & $\mathrm{f}$ & 8.9 & 35.7 & 38.8 & 6 & - & 12 & \\
\hline & Y.H. & 26 & $\mathrm{f}$ & 6.4 & 40.4 & 41.0 & 13 & - & 6 & \\
\hline & F. I. & 20 & $f$ & 6.0 & 42.2 & 48.6 & 14 & - & 18 & \\
\hline & A. I . & 35 & $f$ & 12.6 & 42.7 & 43.5 & 4 & - & 19 & \\
\hline
\end{tabular}


Fig. 1. Inorganic Phosphorus, Greatine Phosphate and ATP in Muscles of Thyrotoxicosis

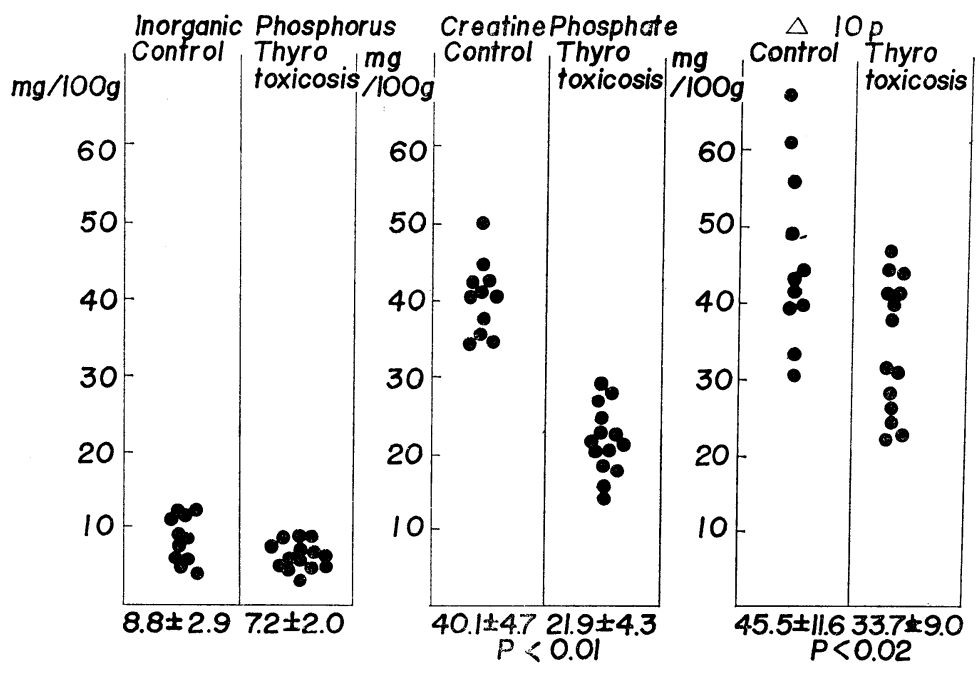

ii ) Creatine 燐酸 (CP) : 筋肉中 CP の成績は対照群では平均 $40.1 \pm 4.7 \mathrm{mg} / 100 \mathrm{~g}$. Mus. w.w. そ対し甲状腺 中毒症群では最高 $29.0 \mathrm{mg} / 100 \mathrm{~g}$. Mus. w.w., 最低 $15.5 \mathrm{mg} / 100 \mathrm{~g}$, Mus. w.w. で平均 $21.9 \pm 4.3 \mathrm{mg} / 100 \mathrm{~g}, \mathrm{Mus,}$ w.w. と対照群より 44\%の減少があり, 両者の間には統計学的に有意の差がみとめられた. $(\mathrm{P}<0.01)$

iii ） ATP : ATP は $\triangle 10 \mathrm{P}$ として測定したものであるが，対照群平均 $45.5 \pm 11.6 \mathrm{mg} / 100 \mathrm{~g}$. Mus. w.w. 亿対

Fig. 2. GP, ATP \& BMR of Thyrotoxicosis BMR

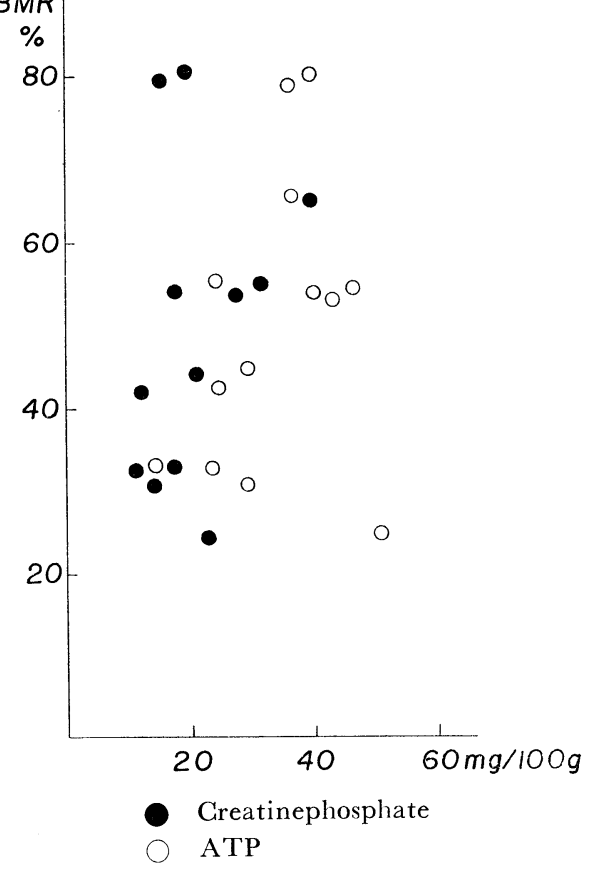

し甲状腺中毒症群は平均 $33.7 \pm 9.0 \mathrm{mg} / 100 \mathrm{~g}$. Mus. w.w. と対照群より $26 \%$ 低值を示しており，2\%以下の危 険率で両者の間に有意の差がみとめられた。

iV) 甲状腺機能と燐酸代謝の関係: 筋肉内 IP, CP, ATP 量と甲状腺機能検查としては BMR，PBI， I ${ }^{131}$ uptake 在用い，乙れら三者と CP，ATP との相関を

Fig. 3. Greatine P \& ATP and Grip Strength

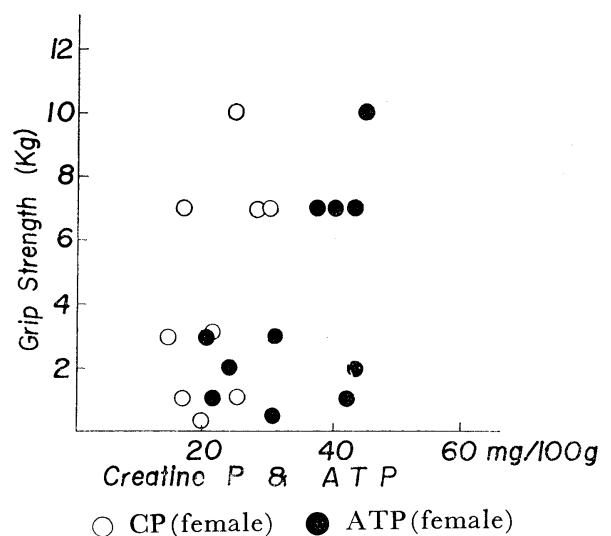


調べた成績は Table 1，Fig. 2 の如くである。14例におけるこれら甲状腺機能と筋 CP，ATP との間には一 定の関係はみとめられなかつた。

v) 握力と燐酸代謝との関係 : 筋菱弱之燐酸代謝の異常之の関係を検討する目的で筋萎弱は学研型握力計 を用いて術前測定した握力(効き腕)を指標とし，てれと CP, ATP との関係を調べた。成績はFig. 3 の如く でCP との間には一定の傾向はみとめられないが，ATP と握力との間には，握力が保存されているものに ATP は高値を示し正の相関がみとめられた。 $(\mathrm{r}=0.63, \mathrm{t}<0.05)$

\section{(B) 酵 素}

i ）血清 Creatine phosphokinase 活性：甲状腺中毒症61例うち男10例，女51例及び非中毒性甲状腺腫18例， 健康人15例の血清 CPK 活性值は Table 2及びFig. 4 亿示す如くである.

Table 2. Serum Creatinephosphokinase Activities in Thyrotoxicosis

\begin{tabular}{|c|c|c|c|c|}
\hline & \multirow{2}{*}{$\begin{array}{l}\text { No. of } \\
\text { cases }\end{array}$} & \multicolumn{3}{|c|}{ Serum $\begin{array}{c}\text { CPK Activities } \\
(\mathrm{u} / \mathrm{hr} / \mathrm{ml})\end{array}$} \\
\hline & & Max. & Min. & Mean \pm S.D. \\
\hline $\begin{array}{l}\text { Thyrotoxic- } \\
\text { osis }\end{array}$ & $61_{\mathrm{f}}^{\mathrm{m}:}: 51$ & 25.9 & 0 & $5.9 \pm 4.6$ \\
\hline $\begin{array}{l}\text { Nontoxic } \\
\text { goiter }\end{array}$ & 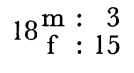 & 6.5 & 0 & $3.3 \pm 1.7$ \\
\hline Normal & $15 \frac{m}{f}: 78$ & 4.6 & 0.3 & $2.4 \pm 1.7$ \\
\hline
\end{tabular}

甲状腺中毒症では最高 $25.9 \mathrm{u} / \mathrm{hr} / \mathrm{ml}$ ，最低 $0 \mathrm{u} / \mathrm{hr} / \mathrm{ml}$ ， 平均 $5.9 \pm 4.6 \mathrm{u} / \mathrm{hr} / \mathrm{ml}$ である。乙れに対し非中毒性甲状 腺腫では最高 $6.5 \mathrm{u} / \mathrm{hr} / \mathrm{ml}$, 最低 $0 \mathrm{u} / \mathrm{hr} / \mathrm{ml}$, 平均 $3.3 \pm 1.7$ $\mathrm{u} / \mathrm{hr} / \mathrm{ml}$ であり，健康人では最高 $4.6 \mathrm{u} / \mathrm{hr} / \mathrm{ml}$, 最低 0.3 $\mathrm{u} / \mathrm{hr} / \mathrm{ml}$, 平均 $2.4 \pm 1.7 \mathrm{u} / \mathrm{hr} / \mathrm{ml}$ であつた。乙れら 3 群 を比較すると非中毒性甲状腺腫群と健康人群では何れ も差がなく, 統計学的にも差異をみとめないが, 甲状 腺中毒症患者では平均 $5.9 \pm 4.6 \mathrm{u} / \mathrm{hr} / \mathrm{ml}$ で健康人及び非中毒性甲状腺腫患者群と比べ明らかに高值を示し， 統計学的に有意の差がみとめられた。（ $\mathrm{P}<0.05)$

ii ）筋 Creatine phosphokinase 活性: 甲状腺中毒症患者27例 (男 4 例, 女23例), 非中毒性甲状腺腫16例 及び健康者の筋肉中CPK 活性の成績はTable 3, Fig. 5 の如くである。健康人は症例数が少なく最高 $162 \mathrm{u} /$

Table 3. Muscle CPK Activities and Thyroid Function

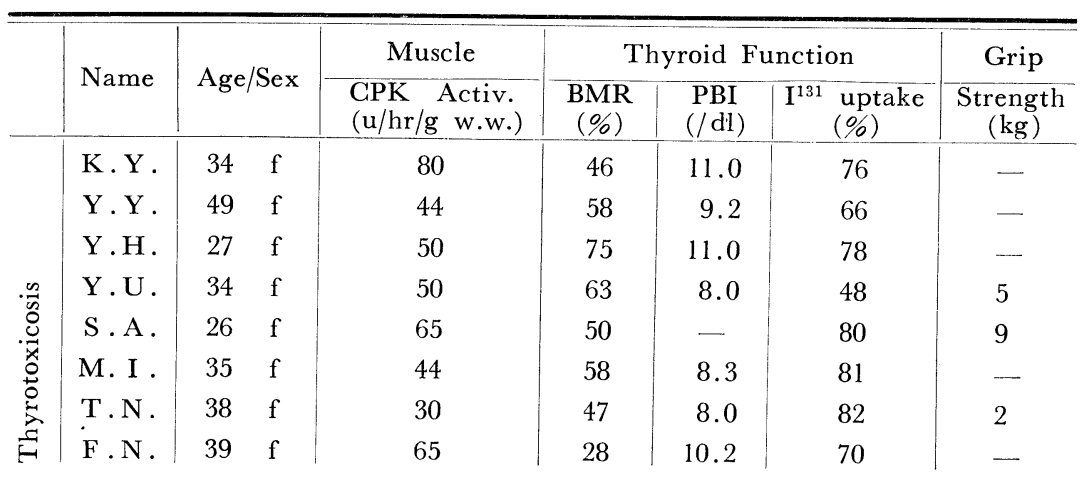

Fig. 4. Serum Greatine Phosphokinase

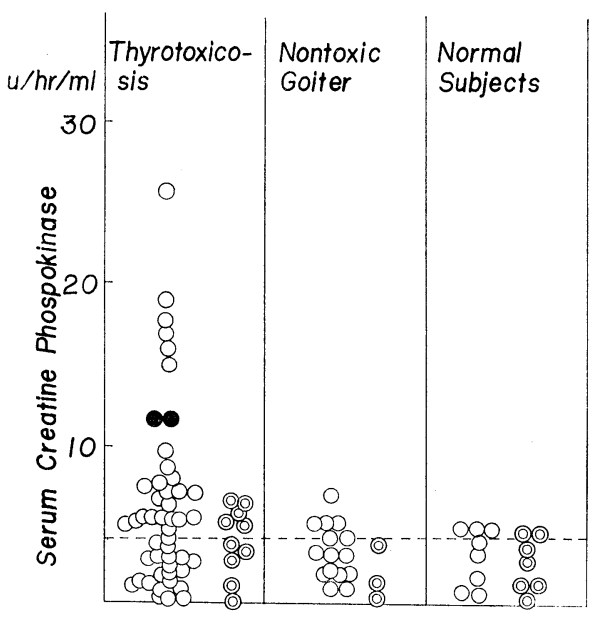

Female (O) Male

- Female, Periodic Paralysis

- Male, Periodic Paralysis 


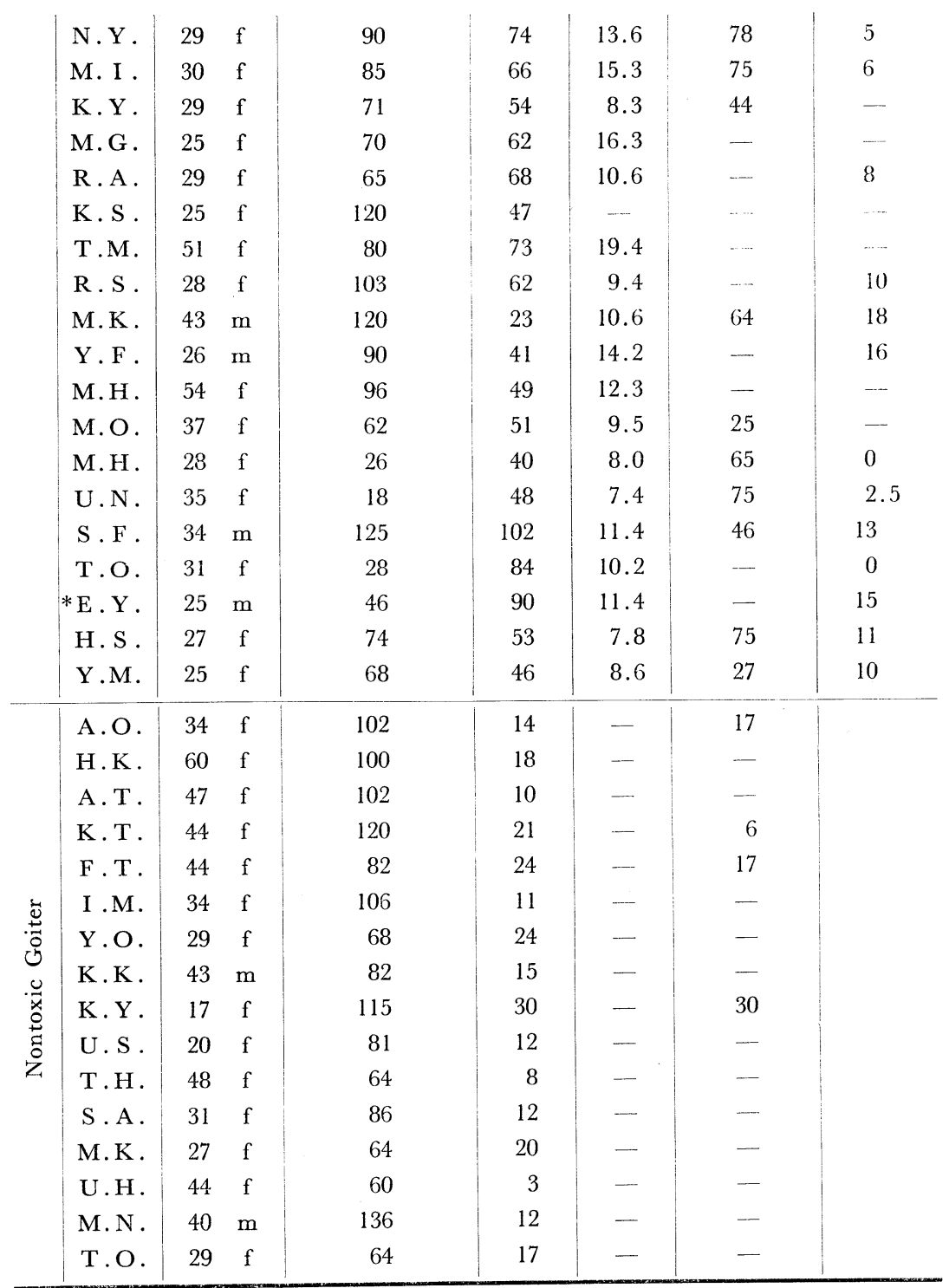

*Periodic paralysis

hr/g. w.w., 最低 $124 \mathrm{u} / \mathrm{hr} / \mathrm{g}$. w.w. であるが, 対照群である非中毒性甲状腺腫では最高 $136 \mathrm{u} / \mathrm{hr} / \mathrm{g}$, w.w., 最低

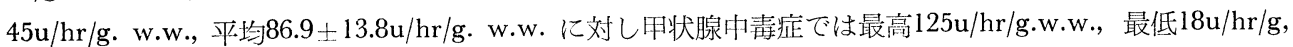
w.w., 平均は71.9土29.7u/hr./g.w.w. で症例の1/3に低值を示すものが諗められたが対照群との間には推計学: 的に有意の差をみとめなかつた.

筋 CPK 活性と甲状腺機能検査 (BMR, PBI， I ${ }^{131}$ uptake) との関係を調べた成績は Table 3，Fig. 6 に 示す如くで，てれらの間には一定の関係がみとめられなかつた。

罹患年数と筋 CPK 活性との関係は Table 4 の如くで26例中罹患年数 1 年以上の長期にわたるものは15例， 1 年未満のものは11例であつた。乙れらの筋 CPK 活性を表の如く60u 以下，60〜100u，100u 以上の 3 段階 
Fig. 5. Creatine Phosphokinase in Muscles

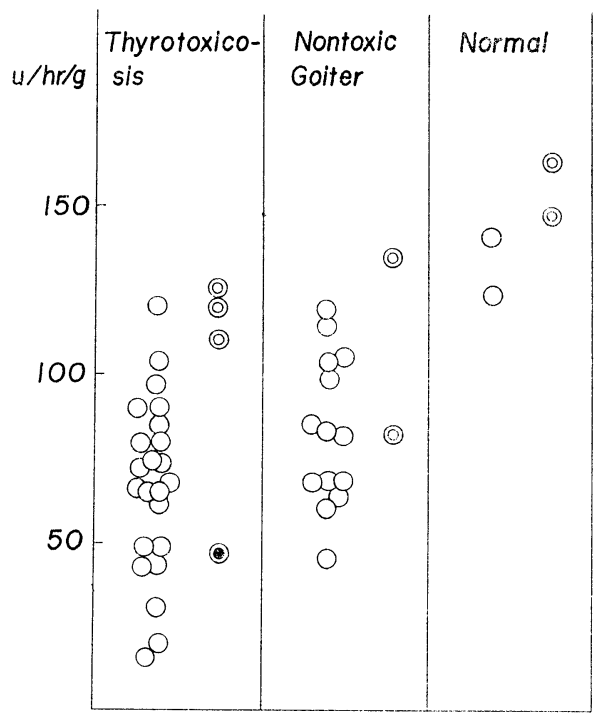

Female (o) Male

- Male Periodic Paralysis

Table 4. Duration of thyrotoxicosis and creatinephosphokinase activities in muscles

\begin{tabular}{c|c|c|c}
\hline & \multicolumn{3}{|c}{$\begin{array}{c}\text { Muscle CPK Activities } \\
\text { (u/hr/g. wet weight })\end{array}$} \\
\cline { 2 - 4 } & $<60$ & $60 \sim 100$ & $100<$ \\
\hline Within 1 year & 1 & 7 & 3 \\
Over 1 year & 5 & 7 & 3 \\
\hline
\end{tabular}

Fig. 7. Grip-strength \& Creatinephosphokinase in Muscle of Thyrotoxicosis

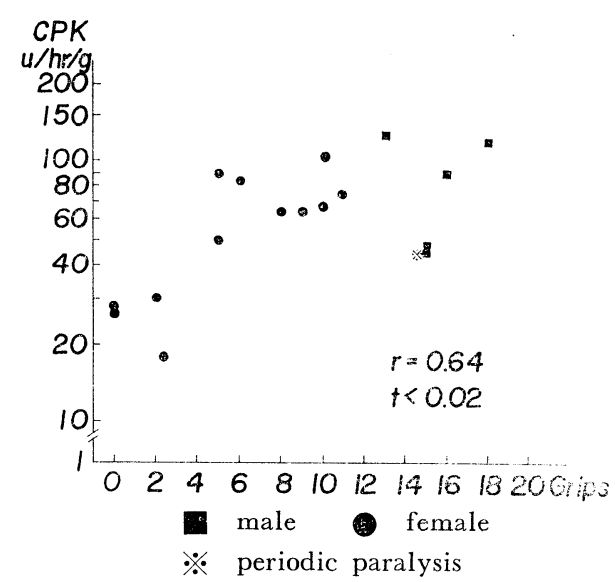

Fig. 6. BMR and Creatine Phosphokinase in Muscles in Thyrotoxicosis

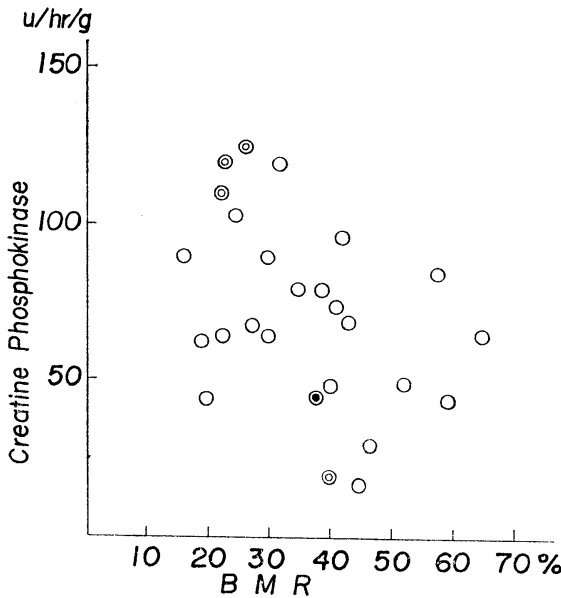

Female () Male

- Male Periodic Paralysis

に分け，その分布をみると， $60 \sim 100 \mathrm{u}$ 又はそれ以上 の価を示すものは両群同数であるが，60u 以下の活性 低下を示すものは 1 年以上の羅患年数者に多く 5 例み とめられたが，1年以内では僅かに 1 例に過ぎず長期 罹患者では活性低下を示すものが多いものと考えられ る。血清 $\mathrm{CPK}$ 活性と罹患年数との間には一定の傾向 はみとめられなかつた。

握力と筋 $\mathrm{CPK}$ 活性との間の関係を示したものは Fig.7の如くである。縦軸は CPK 活性を, 横軸は握力 を半対数目盛でとり, 握力は前述の如く労研 式握力計で検查した，成績は握力の減退して いるものに筋 CPK 活性の低值がみとめられ， $2 \%$ 以下の伦険率で正の相関をみとめた。

\section{(C) 動物実験}

サイロキシン $2.0 \mathrm{mg} / \mathrm{kg}$ を 3 週間投与して 作製した実験的 thyrotoxic rats 5 匹，対照 群 8 匹のIP, CP, ATP はTable 5 の如くであ る. IP は対照群 $12.0 \pm 3.5 \mathrm{mg} / 100 \mathrm{~g}$, Mus. w.w., 実験群 $16.5 \pm 2.4 \mathrm{mg} / 100 \mathrm{~g}$, Mus. w.w. と両者に 有意の差をみとめない，CP は対照群 40.6土 $7.6 \mathrm{mg} / 100 \mathrm{~g}$, Mus, w.w. 亿対しサイロキシン 投与の実験群では $30.5 \pm 8.2 \mathrm{mg} / 100 \mathrm{~g}$, Mus. w.w. と著明に減少し, 又 ATP 方対照群 40.1 $\pm 8.6 \mathrm{mg} / 100 \mathrm{~g}$, Mus. w.w., 実験群 $33.8 \pm 5.6$ 
Table 5. Muscle Phosphorus \& CPK Activities in Thyrotoxicosis Rats

\begin{tabular}{l|c|c|c|c|c|c}
\hline & \multirow{2}{*}{$\begin{array}{c}\text { No. of } \\
\text { Cases }\end{array}$} & \multicolumn{2}{|c|}{ Phosphorus $(\mathrm{mg} / 100 \mathrm{~g}$ mus. wet weight) } & \multirow{2}{*}{$\begin{array}{c}\text { No. of } \\
\text { Cases }\end{array}$} & CPK (u/hr/g w.w.) \\
\cline { 3 - 6 } & 5 & $12.0 \pm 3.5$ & CP & ATP & & \\
\hline Control & 8 & $16.5 \pm 2.4$ & $30.5 \pm 8.2$ & $33.8 \pm 5.6$ & 5 & $104.5 \pm 31.6$ \\
\hline
\end{tabular}

$\mathrm{mg} / 100 \mathrm{~g}$, Mus. w.w. と減少傾向を示し, 統計学的にも有意の差をみとめた.

一方実験的 thyrotoxic myopathy ラッテの筋 CPK 活性は対照群 5 匹の平均は $142.1 \pm 24.3 \mathrm{u} / \mathrm{hr} / \mathrm{g}$. w.w. に対し，実験群 5 匹では104.5 土31.6u/hr/g.w.w.と有意の減少をみとめた.

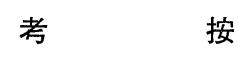

甲状腺中毒症患者における燐酸代謝の報告は極めて少い. Puppel $~^{13)}$ は甲状腺機能六進症患者の血清無機 燐が正常值を示すととを報告している。Wang ${ }^{8)}$ は甲状腺機能充進症では Creatine 代謝を介して燐酸代謝 に密接な関係があるととを指摘している，甲状腺中毒症に Creatine 尿が出現するととは1908年 Schaffer ${ }^{14)}$ により見出され，その後血清 Creatine の上昇, Creatine tolerance の上昇などが報告されている ${ }^{15), 16)}$. 従つて甲状腺機能充進症ではこれら Creatine 代謝の異常につれて Creatine-GP-ATP 系, 即ち Creatine 一燐酸系の代謝異常の存在するととは当然考えられるところである.

$\mathrm{Wang}^{8}$ はサイロキシン投与家鬼の筋肉で CP の減少を報告しているが，甲状腺機能九進症の筋肉内燐酸代 謝については従来全く報告がみられていない。

著者の成績では甲状腺中毒症患者筋肉中 CP 及びATP の著明な減少がみられている. 甲状腺機能杂進症 に筋萎弱がしばしばみられることは Graves, von Basedow 以来よく知られているとてろで著者ら ${ }^{3)}$ の調查 によれば入院患者中軽度の myopathy を示したものは60\%にみられている，従つて生検筋に於ける CP， ATP の如き高 energy 燐酸の変動と筋の萎弱或は萎縮か滵接な関係にあることは当然考えられる。著者が 握力計で調べた筋萎弱の程度とATP との関係をみると筋 ATP の減少が握力の低下と明らかに関係して いるのがうかがわれる。 Lipmann ${ }^{17)}$ ，Borsook \& Dubnoff ${ }^{18)}$ らは Creatine 代謝の主要回路は Creatine が ATP から高 energy 燐酸をうけて GP になり, 脱燐酸により creatinine になるので, ATP の減少が creatine 代謝異常を起すと述べている。 Tiptonら ${ }^{19)}$ はサイロキシン投与白ネズミの肝 ATPase 活性が著明に増加する ことから，サイロキシンによるATP の利用市進がある事を推定しているが，てれに対して Niemyerら ${ }^{20)}$ は ATPase 活性は不変であるという成績を報告している.

著者の成績にみられる ATP 及び CP の減少は, サイロキシンの直接作用による ATPase 活性増加によ るものか，或いは creatine 減少に伴つた CP の産生減少とこれに次ぐ ATP の減少を引き越したものか， 或いは糖代謝殊に Krebs サイクルの代謝異常に伴なつた ATP の産生低下によるもの等にその原因を求め るととができよう。さきに述べた如く甲状腺機能元進症では Creatine 代謝の異常が報告され，動物実験で も筋肉内 Creatine の減少が報告され，又，木下 ${ }^{22}$ は甲状腺中毒症患者の筋肉内に Creatine の低下がある ことをみとめているので, Creatine から CP の産生低下, 次いで ATP の減少というととが最も考えられ る。一方甲状腺機能艺進症では糖代謝の異常が存在するてとはよく知られており，尿糖出現，血糖増加がみ られるととも少くない，従つて解糖系の ATP 産生の低下或は ATP の需要量の増加による減少も否定す るととは出来ない，恐らくこの両者が相まつて CP, ATP の減少をきたしたものと考えられよう.

ATP が物質代謝及び energy 代謝に極めて重荘な役制をしているてとは周知の事実であるが，嗍収縮過

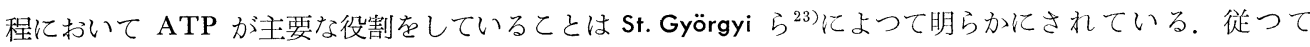
ATP の減少，GP の減少は筋収縮及び弛緩機構における energy 代謝に支障をきたすととが充分考えられ るので甲状腺中毒症における GP, ATP の減少と myopathy の発生とは理論的にも極めて関係が深いもの 
と考えられる.

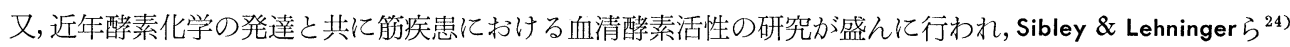
は解糖系に働らく醉素である Aldolase が進行性筋 dystrophy 症に特異的に高値を示す事を報告して以来, 筋疾患の醭素代謝は注目されるようになつてきている。

江橋 ${ }^{26)}$, 杉田 ${ }^{26)}$ は CP の合成・分解に働らく醳素である Creatinephosphokinase (CPK) 飞注目し, 進 行性筋 dystrophy 症では血清 CPK 活性が特異的に高值を示すととを報告している.

著者は甲状腺中毒症患者の血清及び筋肉中 CPK 活性を測定し，血清 CPK 活性の上昇と筋 CPK 活性 の低下の傾向をみとめた，又，実験的 thyrotoxic myopathy ラッテでも筋活性は同様の傾向を示した． 従つて既に述べた筋肉内 CP 及び ATP の堿少の一部は筋 CPK 活性低下によつて生ずるととが考えられ る.筋 CPK 活性と甲状腺機能検查との間には関係がみられていないが，握力との間には正の相関がみられ ており．罹患年数の長いものに筋 CPK 活性低下の強いことがみられている。 てれは甲状腺中毒性 myopathy が㨫患年数の長いものに多いという臨床成績と一致しており, myopathy の形成に筋 CPK 活性低下, ATP 減少が重要な役割を果しているてとを示している.

Askonas $^{27)}$ は動物実験によつてサイロキシンが GPK 活性を抑制するてとを報告し，GPK 活性の低下によ つて ATP 及び CP の減少，次いで Greatine の減少が起るであろうと推定しているが，著者の成績では筋 肉 CPK 活性低下が一次的であるか，二次的であるかは明らかでない．

筋肉内䤃素活性については極めて報告が少なく, Aronson ら $\left.{ }^{28}\right)$ は進行性筋 dystrophy. 亿於いて血清 Aldolase 活性の上昇，筋 Aldolase 活性の低下をみたととから，血清 Aldolase の上昇は筋細胞破壊による遊出 の結果と考えている．乙れに対して Zierler ${ }^{29)}$ は遺伝性筋dystorophy マウスの筋 Aldolase 活性の変動を調 へ，血清 Aldolase 活性の上昇は筋細胞膜の透過性が立進した結果であると解啋している。しかしながら䤀 素の如き高蛋白分子が容易に細胞膜を通過出来るか不かは問題のあるとてろであろう.

甲状腺中毒症で進行性笳 dystrophy 症と同様に血清 CPK 活性が上昇し，筋 CPK 活性が低下したとい う成績は甲状腺中毒症における細胞膜透過性異常の存在が考えられる。Abei \& Abelin ${ }^{300}$ はサイロキシンが 細胞膜に作用し電解質の透過性を変動させるととを報告しているので細胞膜の透過性異常も考光られるが, 一方細胞膜透過性に細胞内代謝か滵接な関係を有すとも考えられるので一概には断定出来ない.

\section{結論}

筋萎弱を伴つた甲状腺中毒症患者の筋肉内燐酸代謝を，IP, CP, ATP, 血清及び筋肉 CPK 活性を中心に 検討し，筋萎弱及びその他の臨床症状との関係を観察した。

(1) 甲状腺中毒症患者14例の胸鎖孚突筋を biopsyして調べた筋肉内 IP, CP, ATP 量は平均 7.2 2.0 , $21.9 \pm 4.3,33.7 \pm 9.0$ (mg/100g. Mus, w.w.) で対照群(非中毒性甲状腺腫) 11 例では IP, CP, ATP はそれぞ れ $8.8 \pm 2.9,40.1 \pm 4.7,45.5 \pm 11.6(\mathrm{mg} / 100 \mathrm{~g} . \mathrm{Mus}, w . w$.$) を示した。即ち甲状腺中毒症群では CP は44\%，$ ATP は26\%の減少がみとめられた。

（2）甲状腺中毒症患者61例，対照として非中毒性甲状腺腫患者18例，健康人15例の血清 CPK 活性を調へ た. 血清 CPK 活性の平均值は甲状腺中毒症 $5.9 \pm 4.6$, 非中毒性甲状腺腫 $3.3 \pm 1.7$, 健康人 $2.4 \pm 1.7$ (u. $/ \mathrm{hr}$./ $\mathrm{ml}$ )で，刘照群に比べ甲状腺中毒症では統計学的に有意の上昇がみとめられた。

（3）甲状腺中毒症患者 27 例，非中毒性甲状腺腫患者 16 例，健康人 4 例の筋 CPK 活性を調べた。筋肉内 CPK 活性の平均値はそれぞれ71.9 $29.7,86.9 \pm 13.8,144 \pm 15$ (u./hr./g. wet. wt.) で, 甲状腺中毒症の1/3に 異常低值を示すものをみとめたが, 統計学的に有意の差はみとめられなかつた。

又, 甲状腺中毒症のうち，1 年以上の長期罹患者で筋 CPK 活性の低下を示すものは 1 年未満の短期羅患 者より多数にみとめられた。

(4) 甲状腺機能と筋 GP, ATP, 筋 CPK 活性との間には㥵関はみとめられないが，握力と筋 ATP, 筋 CPK 活性との間には相関がみとめられた。従つて thyrotoxic myopathy にみられる筋萎弱及び筋萎縮 
の原因と筋肉内 CPK 活性及び ATP の減少が極めて密接な関係にあることが考えられる.

(5) ラッテにサイロキシン $2.0 \mathrm{mg} / \mathrm{kg}$ を 3 週間投与して実験的 thyrotoxic myopathy を作製し，筋肉中 のIP, GP, ATP, 筋 CPK 活性を測定した。成績は甲状腺中毒症患者の生検笳にみとめられたものと同様の 傾向を示し，CP，ATP の減少と筋 CPK 活性の低下をみとめた.

(6)、甲状腺機能元進症における燐酸代謝異常の原因，燐酸代謝異常と甲状腺ホルモンとの関係について考 察を加えた。

尚，本論文の要旨は第34回日本内分泌学会総会に打いて報告した。

稿を終るに臨んで御指導, 御校閲を睗わつた阿部教授, 里吉助教授に深甚なる謝意を表すると共に, 種々 御便宜を頂いた伊藤甲状腺研究所長伊藤国彦博士に感謝致します。

な扢，本研究の一部は文部省科学研究費によるものである.

文献

1) BATHBURST, L.W. : Lancet $2: 529$ ，(1859) (2)上り).

2) MILLIKAN, C.H. \& HAINS, S.F. : Arch. Int. Med., 92 : 5, (1953).

3) 里吉他 : 内科, $7: 145,1961$ (昭和36年).

SATOYOSHI, E., MURAKAMI, K., KOWA. H., KINOSHITA, M., NOGUGHI, K., HOSHINA, S., NISHIYAMA, Y., \& ITO, K. : Neurology, $13: 645,(1963) . \quad 5)$ HOCH, F.L. \& LARDY, H.A. : Proc. Nat. Acad. Sci., 40 : 909, (1954).

6) MALEY, G.H. \& LARDY, H.A. : J. Biol. Chem., 215 : 377, (1955) 7) JOHNSON, P.G., POSEY, A.F., PATRIEK, D.R. \& GAPUTTO, R. : Am. J. Physiol., 192 : 275, (1958). 8) WANG, E. : Act. Med. Scand. Supp., 169, (1946). BODANSKY, M. : J. Biol. Chem., $109: 615$, (1935). 10) MARTIN, J.B. \& DOTY, D.M. : Anal. Chem., $21: 965$, (1949). 11) ALLEN, R.J.L. : Biochem. J. $34: 858$, (1940). KUBY, S.A., NODA, L.A. \& LARDY, H.A. : J. Biol. Chem., $209: 191$, (1954). 13) PUPPEL, I.D., GROSS, H.T., McCORMICK, E.K. \& HERDLE, E. : Surg. Genecolog. \& Obst., 81 : 243, (1945). 14) SHAFFER, P.A. : Am. J. Physiol., 23 : 1, (1908).

15) PETERS, J.H., SCHWARZ, R. \& ASSOCIATES : J. Clin. Invest., $30: 799$, (1951).

16) THORN, G.H. : Endocrinology, $20: 628$, (1936). 17) LIPMANN, F. : Adv. Enzym., $1: 99$, (1941). 18) BORSOOK, H. \& DUBNOFF, J.W. : J. Biol. Chem., $168: 247$, (1947).

19) TIPTON, S.R., WELDEN, F. \& WEISS, A.K. : Am. J. Physiol., 180 : 321, (1955). 20) NIEMYER, H., GRANE, R.H., KENEDY, E.P. \&. LIPMANN, F. : Fed. Proc., $10: 229$, (1951). 21) ABELINE, I. \& STICHTIN, W. : Biochem. Zeit., $228: 250$, (1930). 22) 木下真男 : (未発表). 23) St. GYÖRGYI, A. : Chemical Physiology of Contraction in Body and Heart Muscle, New York, Academic Press (1953). 24) SIBLEY, J.A. \& LEHNINGER, A. : J. Biol. Chem., $177: 859$, (1949). 25) EBASHI, S., TOYOKURA, Y., MOMOI, H. \& SUGITA, H. : J. Biochem., 46 : 1, (1959). 26) 杉田秀夫 : 精神神経誌，62:106，1960 (昭和35年). 27) ASKONAS, B.A. : Nature, $167: 933$, (1951). 28) ARONSON, S.B. \& VOLK, B.W. : Am. J. Med., 22 : 414, (1958). 29) ZIERLE R, K.L. : Bull. Johns Hopikns Hosp., 102 : 17, (1958). 30) AEBI, H. \& ABELIN, I. : Biochem. Zeit., $324: 364$, (1953). 